\section{Pronival rampart and protalus rampart: a review of terminology}

In the late 1980s, a series of letters in this journal (e.g. Butler, 1986, 1987; Ballantyne, 1987; Porter, 1987; Unwin, 1988; Wilson, 1988) described the history of the early work on 'pro-talus ramparts'. These letters also highlighted that many different terms, such as winter-talus ridge (Daly, 1912), nivation ridge (Behre, 1933) and protalus rampart (Bryan, 1934), have been used to denote these discrete debris accumulations found at the foot of firn fields. The most common of these terms was 'protalus rampart' and it became entrenched in the literature (Ballantyne, 1987) until it evolved yet again when Shakesby and others (1995) proposed replacing the descriptor 'protalus' with 'pronival' since they concluded that the latter provided a universally appropriate term to describe firn-foot debris accumulations; regardless of their position on the slope. The descriptor 'pronival' has largely gained acceptance in the literature (e.g. Hedding, 2008), while some studies (e.g. Hedding and others, 2010) use 'pronival (protalus)' so as to avoid any ambiguity. Several recent studies (e.g. Lewis, 2011) continue to use the descriptor 'protalus' since interchanging the descriptor 'protalus' with 'pronival' has not been very problematic in the literature thus far. Scapozza and others (2011) have, however, recently proposed that the term 'protalus rampart' be used to define small permafrost creep phenomena (embryonic rock glaciers) in contrast to the former usage of the term to describe pronival ramparts. This may lead to some confusion in the literature because the differentiation of embryonic rock glaciers from pronival ramparts may prove difficult, particularly in relict features, since these features are morphologically similar. To further compound the difficulty in differentiating these features, many of the existing 'diagnostic criteria' used to identify pronival ramparts are plagued by circular arguments and assumptions about typical form, constituent material and genesis (Shakesby, 1997). Therefore, this letter aims to determine whether the terms 'protalus rampart' and 'pronival rampart' can coexist in literature by investigating the applicability of existing 'diagnostic criteria' that may be used to differentiate embryonic rock glaciers from pronival ramparts.

A pronival rampart, formerly referred to as a protalus rampart, is defined as a ridge, series of ridges or ramp of debris formed at the downslope margin of a perennial or semi-permanent snow bed, which is typically located near the base of a steep bedrock slope in a periglacial environment (Shakesby, 2004). Shakesby (1997) highlights that pronival ramparts are mostly viewed as separate, independently produced forms of modified talus occurring in a nondevelopmental morphological continuum of unmodified talus, but other researchers (e.g. Haeberli, 1985) argue that ramparts represent part of a linear developmental continuum of rock-glacier and moraine formation. Stemming from the work of Haeberli (1985), Scapozza and others (2011) have recently proposed that the term 'protalus rampart' be used to define small permafrost creep phenomena (embryonic rock glaciers). The alternative usage of the term 'protalus rampart' by Scapozza and others (2011) within the new genetic definition of active rock glaciers as the visible expression of cumulative deformation by long-term creep of ice/debris mixtures under periglacial conditions (Berthling, 2011) may, in theory, allow the term 'protalus rampart' to coexist with 'pronival rampart'. However, the morphological similarities of pronival ramparts and incipient or immature rock glaciers make it difficult to distinguish between these features in the field. Pronival ramparts are typically differentiated from embryonic rock glaciers through the identification of specific morphological and sedimentological characteristics (Hedding and others, 2010), but use of these 'diagnostic criteria' may prove inappropriate when differentiating embryonic rock glaciers from pronival ramparts.

Curry and others (2001) indicate that well-developed protalus rock glaciers can be differentiated from pronival ramparts since these features are typically lobate in plan form, greater in length (downslope) than in width (acrossslope), exhibit a convex distal slope, terminate $>70 \mathrm{~m}$ from the talus slope and most distinctively they comprise meandering and closed depressions, downslope ridges and furrows, and transverse ridges and depressions. Many of these 'diagnostic criteria' are, however, inappropriate for the positive identification of embryonic rock glaciers since these features would lack many of the characteristics of welldeveloped protalus rock glaciers; making it extremely difficult to differentiate these features from pronival ramparts in the field. To further complicate the differentiation of pronival ramparts from embryonic rock glaciers, Shakesby (1997) highlights that, although rampart development is the result of supranival and subnival processes, pronival ramparts may also comprise permafrost and exhibit associated permafrost creep. Therefore, the identification of permafrost creep cannot be used to positively differentiate embryonic rock glaciers from pronival ramparts. In addition, Shakesby and others (1999) have identified snow creep as a subnival process responsible for pronival rampart formation, and snow creep may generate various morphological characteristics that may be exhibited by embryonic rock glaciers derived from permafrost creep. Thus this letter rejects the alternative usage of the term 'protalus rampart' to denote embryonic rock glaciers until such time as diagnostic criteria are identified by which pronival ramparts can be differentiated from other talus-derived landforms. Instead, it is suggested that 'protalus rock glacier' be used to denote embryonic rock glaciers. This is critical to avoid the incorrect identification and associated palaeoenvironmental inferences that have plagued research on pronival ramparts in the past; particularly since relict protalus rock glaciers could be used to infer former permafrost conditions whereas pronival ramparts do not require permafrost for their formation.

Department of Geography

University of South Africa

Florida Campus

Florida 1710, South Africa

E-mail: heddidw@unisa.ac.za

27 October 2011

\section{REFERENCES}

Ballantyne, C.K. 1987. Correspondence. Winter-talus ridges, nivation ridges, and pro-talus ramparts. J. Glaciol., 33(114), 246-247.

Behre, C.H. 1933. Talus behavior above timber in the Rocky Mountains. J. Geol., 41(6), 622-635.

Berthling, I. 2011. Beyond confusion: rock glaciers as cryoconditioned landforms. Geomorphology, 131(3-4), 98-106.

Bryan, K. 1934. Geomorphic processes at high altitudes. Geogr. Rev., 24(4), 655-656. 
Butler, D.R. 1986. Correspondence. Winter-talus ridges, nivation ridges, and pro-talus ramparts. J. Glaciol., 32(112), 543.

Butler, D.R. 1987. Correspondence. Concerning early descriptions of pro-talus ramparts. J. Glaciol., 33(114), 248-249.

Curry, A.M., J. Walden and D.A. Cheshire. 2001. The Nant Ffrancon 'protalus rampart': evidence for Late Pleistocene paraglacial landsliding in Snowdonia, Wales. Proc. Geol. Assoc., 112(4), 317-330.

Daly, R.A. 1912. Geology of the North American Cordillera at the forty-ninth parallel. Geol. Surv. Can. Mem., 38.

Haeberli W. 1985. Creep of mountain permafrost: internal structure and flow of Alpine rock glaciers. Mitt. VAW/ETH 77.

Hedding, D.W. 2008. Spatial inventory of landforms in the recently exposed Central Highland of sub-Antarctic Marion Island. S. Afr. Geogr. J., 90(1), 11-21.

Hedding, D.W., K.I. Meiklejohn, J.J. Le Roux, M. Loubser and J.K. Davis. 2010. Some observations on the formation of an active pronival rampart at Grunehogna Peaks, Western Dronning Maud Land, Antarctica. Permafrost Periglac. Process., 21(4), 355-361.

Lewis, C.A. 2011. Late Quaternary environmental phases in the Eastern Cape and adjacent Plettenberg Bay-Knysna region and Little Karoo, South Africa. Proc. Geol. Assoc., 122(1), 187-200.
Porter, S.C. 1987. Correspondence. Early description of pro-talus ramparts. J. Glaciol., 33(114), 247-248.

Scapozza, C., C. Lambiel, L. Baron, L. Marescot and E. Reynard 2011. Internal structure and permafrost distribution in two alpine periglacial talus slopes, Valais, Swiss Alps. Geomorphology, 132(3-4), 208-221.

Shakesby, R.A. 1997. Pronival (protalus) ramparts: a review of forms, processes, diagnostic criteria and palaeoenvironmental implications. Progr. Phys. Geogr., 21(3), 394-418.

Shakesby, R.A. 2004. Protalus ramparts. In Goudie A., ed. Encyclopedia of geomorphology, Vol. 1. London, Routledge, 813-814.

Shakesby, R.A., J.A. Matthews and D. McCarroll. 1995. Pronival ('protalus') ramparts in the Romsdalsalpane, southern Norway: forms, terms, subnival processes, and alternative mechanisms of formation. Arct. Alp. Res., 27(3), 271-282.

Shakesby, R.A., J.A. Matthews, L.J. McEwen and M.S. Berrisford. 1999. Snow-push processes in pronival (protalus) rampart formation: geomorphological evidence from Smörbotn, Romsdalsalpane, southern Norway. Geogr. Ann., 81A(1), 31-45.

Unwin, D.J. 1988. Correspondence. Early descriptions of pro-talus ramparts. J. Glaciol., 34(116), 141.

Wilson, P. 1988. Correspondence. Early descriptions of pro-talus ramparts. J. Glaciol., 34(116), 141-142. 